Commentary

\title{
Why We Should Keep Studying Good (and Everyday) Participation: An Analogy to Political Participation
}

\author{
Neta Kligler-Vilenchik \\ Department of Communication and Journalism, The Hebrew University of Jerusalem, 9190501 Mount Scopus, Israel; \\ E-Mail: neta.kv@mail.huji.ac.il
}

Submitted: 17 September 2018 | Accepted: 19 September 2018 | Published: 8 November 2018

\begin{abstract}
Research on participation is currently characterized by a trend towards studying its "darker" sides. In this commentary, I make an argument for why we should keep studying good participation. In addition, I claim that the flipside of studying exceptional case studies of participation shouldn't be only focusing on dark participation, but on everyday, mundane forms of participation, that may happen in surprising contexts (such as non-proprietary platforms) and may take different shapes. To make these claims, I introduce a case study of "good participation" in news production processes, and explain why it may merit this distinction. I then use a three-pronged analogy to the cognate field of political participation to show what it can tell us about good-and everyday-participation in the news.
\end{abstract}

\section{Keywords}

citizen journalism; dark participation; everyday participation; good participation; news; participatory journalism; political participation; social media

\section{Issue}

This commentary is part of the issue "News and Participation through and beyond Proprietary Platforms in an Age of Social Media", edited by Oscar Westlund (Oslo Metropolitan University, Norway) and Mats Ekström (University of Gothenburg, Sweden).

(C) 2018 by the author; licensee Cogitatio (Lisbon, Portugal). This article is licensed under a Creative Commons Attribution 4.0 International License (CC BY).

\section{Introduction}

Academic scholarship is somewhat notorious for being shaped by trends. In his essay on "Dark Participation" in this issue, Thorsten Quandt (2018) begins by vividly describing the early 2000s when journalism scholarship was seeped deep in an optimistic trend, with promises that user participation will help revolutionize the outdated legacy media. Quandt's tales of the optimism in journalism research reminded me of a similar enthusiasm in a cognate field-that of youth political participation. This area too was strongly influenced in the early 2000s by emerging scholars who, to some extent, saw online youth participation as holding the promise to mend an outdated institution -in this case, the political system.

One does not need to look far to determine that much communication research is now trending toward "the dark sides of participation" (in this issue, see also Anderson \& Revers, 2018; Lewis \& Molyneux, 2018; Robinson \& Wang, 2018), and this trend may be partic- ularly pronounced in the field of political participation. As Quandt (p. 44) succinctly states, "positive forms of participation now seem awfully outdated". The attention paid to "fake news", incivility, the role of bots and foreign influencers-all those factors that Quandt describes under "dark participation" in the context of participation in news-are also occupying researchers of political participation, who, particularly in the context of the surprising outcomes of the 2016 US Presidential election, are similarly devoting attention to "wicked actors", "sinister motives", and "nefarious processes/actions" (Quandt, 2018, p. 41).

Although we are now-both in political participation and in journalism studies-in a "dark participation" trend, some of my research presents an outlier, stubbornly insisting -in a currently unfashionable way-to focus on what Quandt (p. 37) calls "the light side". It may be that I am simply a late adopter, still stuck in the old fad, but in what follows I will make the case as to why there is merit to focus on the more positive aspects, and not 
to forget the benefits of examining good participation. More importantly, perhaps, I will argue that the remedy to focusing on positive extremes should be a focus not solely on negative (extremes), but rather on the mundane and everyday.

To do so, I will first introduce a case study that may count as "good participation" in news production processes, and explain in what ways it may merit this distinction. As I'll readily admit, I am thus making the mistake identified by Quandt as plaguing the overlyoptimistic research on participatory journalism, though I'll aim to justify why I still do so. Next, I will use an analogy to the cognate field of youth political participation, in order to make three inferences that may be useful for considering good-and everyday-participation in journalism. Though we may be reaching it from opposite sides, my end goal will be very similar to that of Quandt's: to encourage "the development of integrative theories on the conditions of participation that are neither driven by wishful thinking nor doom and gloom" (Quandt, 2018, p. 44).

\section{A Case Study of "Good Participation"}

In a forthcoming article (Kligler-Vilenchik \& Tenenboim, in press), my co-author Ori Tenenboim and I examine the case study of a large-scale instant-messaging group on the application WhatsApp, opened in 2015 by prominent Israeli journalist Tal Schneider for her followers. The group is open to anyone willing to pay a nominal subscription fee. In the group, subscribers both receive and share information and updates on the behind-the-scenes of the news, participate in crowdsourced interviews with politicians and pundits, and conduct vibrant discussions around the days' news, both with the journalist and among themselves.

Why may we classify this group as exemplifying good participation? As we show, based on a combination of in-depth interviews and a qualitative analysis of the group chat content, this group provides shared benefits to both the journalist and her audiences, and thus presents an empirical example of "reciprocal journalism" (Lewis, Holton, \& Coddington, 2014). The audiencesmostly self-defined "news junkies" who love the newsenjoy "information gifts" (Lewis, 2015) provided to them both by the journalist and by other group members. The journalist receives monetary support, but more importantly, benefits from audience participation in producing journalistic knowledge. Importantly, and unlike many other empirical cases (e.g., Singer et al., 2011), audience members' participation is not limited to only symbolic participation, but rather occurs across the newsproduction process.

\subsection{A Mea Culpa}

Describing the early research on participatory journalism, Quandt (p. 39) claims that one of its limitations was the focus on "case studies and 'outstanding' bestpractice examples" that pronounce "the extreme", while "neglecting the (potentially boring, but more prevalent) normal". This is a fair critique to make of the case study we examine. It is indeed extreme: its participants are characterized by especially high interest in the news, which accounts for their especially high motivation to participate in news production processes. Moreover, the journalist administering the group opened it at a time when she was not bound to a mainstream media organization, and thus enjoyed much institutional freedom, as well as an acute need for additional data sources. In these ways and others (further detailed in the article), this can indeed be classified as an "outstanding" example. In what follows, I'll explain-through an analogy to political participation-why such examples of good participation should still merit our scholarly attention and, no less importantly, why they need to be supplemented with research on mundane, everyday participation.

\section{What an Analogy to Political Participation Can Tell Us about Studying Good (and Everyday) Participation in the News}

\subsection{Who Participates, Where and How?}

Quandt critiques early research on participatory journalism for focusing on rare examples, rather than the "normal". Yet the "dark participators" he discusses-as he himself points out-also do not represent the participation of most people, but of a (different) select few. Quandt (p. 44) cautions media and communication research to not take "the exception as the rule".

Indeed, most people aren't dark participators nor avid citizen journalists, just like most people don't participate much politically. I echo Quandt's claim that it may be naïve to expect most people to do so. In the field of political participation, Michael Schudson's (1998) The Good Citizen has addressed the unrealistic expectations we often have of citizens in democracy. In most areas of life, Schudson claims, we do not attempt to independently supply all our needs, but rather rely on the work of others. "Why, then, in public life, do we expect people to be political backpackers?", he asks (Schudson, 1998, pp. 310-311). Schudson suggests we might instead envision most citizens as "monitorial citizens", who scan the informational environment and are only alerted to action when there is immediate need.

Similarly, it is probably a fallacy to expect most users to take an active, daily part in participatory journalism. In this way, the participants of the journalistic WhatsApp group, who on a day-to-day basis take part in discussing and even producing the news, are indeed the outliers. Yet there is still good reason to continue to pay attention to the few who do take part (in either politics or participatory journalism). Precisely because they are a minority, they accrue more relative power (see Holton \& Belair-Gagnon, 2018, on other overlooked influencers in 
journalism). Some of the WhatsApp group participants told us, for example, that they serve as opinion leaders to their less informed friends and acquaintances. The "good participation" of the few thus merits our continued attention.

But this doesn't mean that most people aren't participating at all. The opposite of studying the extraordinary should not necessarily take the form of studying "dark participation", but rather mundane, everyday participation. In my own research on youth political participation, this means examining the myriad ways and contexts young people find to express themselves politically. Youth political participation happens not only in the ways we expect (e.g., voting) or the places we expect (e.g., the websites of political parties), but can take the form of, for example, creative production of anti-Trump computer games on a website that teaches kids programming skills (see Kligler-Vilenchik \& Literat, 2018). This means we often have to adjust our expectations of what participation looks like, and where it takes place.

Returning to journalism, this links us back to this special issue's focus on non-proprietary platforms. When we don't expect participation in news processes to happen only on the websites of news media, but rather examine those non-proprietary platforms where people are most active anyway, we may encounter new and surprising practices. In terms of the how of participation, we should keep our eyes open for emergent ways to participate, that may differ from what the early optimistic scholarship has expected, but may still be meaningful to participants. One area that may merit further attention is information sharing via social media as a mundane, everyday form of participation in the news, that is very prevalent and routinized (see Hermida, 2014). What are its merits? Could it be usefully considered as a form of participatory journalism?

\subsection{Why Are They Participating?}

Quandt devotes much important attention to the question of motivation in participatory journalism. As he claims, research on participatory journalism has not given sufficient thought to the question, "why should anybody want to be a 'citizen journalist'?" (p. 39). In dark participation, as he shows, this problem is "solved", as dark participants are highly driven - though by quite sinister motives.

Here again the merit of studying good participation can be gleaned. The participants in the journalistic WhatsApp group are highly intrinsically motivated to participate in the news, for the simple reason that they are, as one participant told us, "people who love the news in terms of being informed and informing others" (KliglerVilenchik \& Tenenboim, in press).

In political participation, political interest is known to be one of the most important predictors for political participation (Verba, Nie, \& Kim, 1978). But it is a very stable construct, that establishes in youth and is hard to shape afterwards. In the analogy, we can assume that interest in the news would be a strong predictor for participation as a citizen journalist - that was certainly the case for the participants of the journalistic WhatsApp group. Paying attention to those "news junkies" can help us understand the lifelong processes that led to their increased interest in the news, and perhaps learn how to encourage interest in the news in general.

Parallel to that, we should also be paying attention to everyday participation. Many people are interested in "news"-but not necessarily the "hard news" we usually pay attention to. Could we find interesting forms of participatory journalism out there if we open up our purview to the sorts of news many people are much more interested in, such as entertainment or sports? What may such forms of participation teach us?

\subsection{Why Do We Want Them to Participate?}

Which brings us to the third point. We are by now hopefully in agreement that most people are not engaging in good participation or dark participation-they are either not participating, or participating in everyday, mundane ways that we are not paying much attention to. The question is, why do we want to encourage them to participate? In politics the answer is quite straightforward: we want to encourage participation because we believe it is beneficial for citizens-because more political participation (should be) translated into more political influence (Verba, Schlozman, \& Brady, 1995). But in journalism research, do we have a good answer to the question why people should participate in the news, and why we should encourage them to do that? As Quandt points out, the merit can't just be free labor for the news media industry. One way to address this question may be through the concept of reciprocal journalism (Lewis et al., 2014), which highlights shared benefits for both journalists and community members.

\section{Conclusions: Why We Should Keep Studying Good-and Everyday-Participation}

I echo Quandt's call to study the "(potentially boring, but more prevalent) normal" (p. 39). But studying the normal shouldn't mean (only) studying the dark-it means opening our eyes to the mundane and everyday. It means coming with less pre-conceived notions of what participation should look like and where it should take place. Moreover, the study of the normal should continue to be complemented by studying the good. This is vital in order to know what we'd like to achieve, and get a better sense of how to do so. There is a continued need to understand good participation, but instead of an abstraction derived from idealistic notions, we should do so in a way that is empirically informed by the actual participation practices of real people (even if a select few). "Case studies and 'outstanding' best-practice examples" (Quandt, 2018 , p. 39) are still important in showing us the way. 


\section{Acknowledgements}

The author thanks Ori Tenenboim, with whom the argument around the journalistic WhatsApp group was developed; as well as journal editor Oscar Westlund for suggesting the theme for this commentary.

\section{Conflict of Interests}

The author declares no conflict of interests.

\section{References}

Anderson, C. W., \& Revers, M. (2018). From counterpower to counter-pepe: The vagaries of participatory epistemology in a digital age. Media and Communication, 6(4), 24-35.

Hermida, A. (2014). Tell everyone: Why we share \& why it matters. Toronto: Doubleday Canada.

Holton, A. E., \& Belair-Gagnon, V. (2018). Strangers to the game? Interlopers, intralopers, and shifting news production. Media and Communication, 6(4), 70-78.

Kligler-Vilenchik, N., \& Literat, I. (2018). Distributed creativity as political expression: Youth responses to the 2016 US presidential election in online affinity networks. Journal of Communication, 68(1), 75-97.

Kligler-Vilenchik, N., \& Tenenboim, O. (in press). Sustained journalist-audience reciprocity in a meso- newspace: The case of a journalistic WhatsApp group. New Media \& Society.

Lewis, S. C. (2015). Reciprocity as a key concept for social media and society. Social Media + Society, 1(1). https://doi.org/10.1177\%2F2056305115580339

Lewis, S. C., Holton, A. E., \& Coddington, M. (2014). Reciprocal journalism: A concept of mutual exchange between journalists and audiences. Journalism Practice, 8(2), 229-241.

Lewis, S. C., \& Molyneux, L. (2018). A decade of research on social media and journalism: Assumptions, blind spots, and a way forward. Media and Communication, 6(4), 11-23.

Quandt, T. (2018). Dark Participation. Media and Communication, 6(4), 36-48.

Robinson, S., \& Wang, Y. (2018). Networked news participation: Future pathways. Media and Communication, 6(4), 91-102.

Schudson, M. (1998). The good citizen: A history of American civic life. New York, NY: The Free Press.

Singer, J. B., Domingo, D., Heinonen, A., Hermida, A., Paulussen, S., Quandt, . . Vujnovic, M. (2011). Participatory journalism: Guarding open gates at online newspapers. Oxford: Wiley-Blackwell.

Verba, S., Schlozman, K. L., \& Brady, H. (1995). Voice and equality: Civic voluntarism in American politics. Cambridge, MA: Harvard University Press.

\section{About the Author}

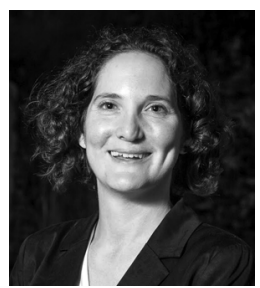

Neta Kligler-Vilenchik (PhD University of Southern California, 2015) is Assistant Professor of Communication at the Hebrew University of Jerusalem, Israel. Her research interests revolve around changing forms of civic and political participation in the context of the new media environment. Her work has been published in outlets such as the Journal of Communication, New Media \& Society, International Journal of Communication, Computers in Human Behavior, and Social Media + Society. She is also a co-author on the book By Any Media Necessary: The New Youth Activism (NYU Press, 2016). 